a pitch of $38.5 \AA$. The strongest reflection in this case occurs on the 11 th layer line with a spacing of 3.5 $\AA$. As before, this reflection splits into two (Fig. $2 b$, bottom), and the true meridional reflection occurs on the 12th layer line with a spacing of 3.20 $\AA$. The helix with a hetero sequence thus has 12 residues per turn (n) and a rise per residue (h) of $3.20 \AA$, whereas the helix with homo $\mathrm{A}$ and T sequences has $n$ and $h$ values of 13 and $3.26 \AA$, respectively. Both have $B$ conformation and sugar pucker in the $\mathrm{C}_{2}$ ' endo family.

Received 15 November; accepted 1 December, 1993
Keliang Liu, H. Todd Miles, Kevin D. Parris and V. Sasisekharan

Laboratory of Molecular Biology, NIDDK, National Institutes of Health, Bethesda, Maryland 20892, USA

\section{References}

1. Lyamichev, V.I., Mirkin, S.M. \& FrankKamenetsky, M.D. J. biomol. Struct. Dyn. 3. 667-667 (1986).

2. Htun, H. \& Dahlberg, J.E. Science 241, 1791-1796 (1988).

3. Kohwi, Y. \& Kohwi-Shigematsu, T. Proc. natn. Acad. Sci. U.S.A. 85, 3781-3785 (1988).

4. Mirkin, S.M., Lyamichev, V.I., Drushlyak, K.N., Dobrynin, V.N., Filipovand, S.A. \& Frank-Kamenetsky, M.D. Nature $\mathbf{3 3 0}$,
495-497 (1987)

5. Cooney, M., Czernoszcwicz, G., Postel, E. Flint, S.J. \& Hogan, M.E. Science 241, 456459 (1988).

6. Moser, H.E. \& Dervan, P.B. Science $\mathbf{2 3 8}$ 645-650 (1987).

7. Baran, N., Lapidot, A. \& Manor, H. Proc nath Acad Sci. US.A. 88, 507-511 (1991)

8. Helene, C., \& Toulme, J.J. Biochim. biophys. Acta. 1049, 99-125 (1990).

9. Arnott, S. \& Selsing, E J molec Biol. 88, 509-521 (1974).

10. Arnott, S., Bond, P.J. Selsing, E. \& Smith, P.J.C. Nucleic Acids Res. 3, 2459-2470 (1976)

11. Howard, F.B. Miles, H.T., Liu, K., Frazier J., Raghunathan, G. \& Sasisekharan, V. Biochemistry 31, 10671-10677 (1992).

12. Raghunathan, G. Miles, H.T \& Sasisekharan, V. Biochemistry 32, 455-462 (1993).

\title{
Shoeing Ribonuclease
}

\author{
IMAGE \\ UNAVAILABLE \\ FOR COPYRIGHT \\ REASONS
}

The horse shoe-shaped protein illustrated above is porcine ribonuclease inhibitor (RI: reproduced from B. Kobe and J. Deisenhofer, Nature 366, (in the press). The striking appearance of the molecule arises from 15 alternating A-type and B-type leucine-rich repeats (LRR). Each repeat consists of a $\beta$-sheet (red) connected to an $\alpha$-helix (blue) via a short loop (green). The repeats are flanked by an unrelated $\beta$-sheet and $\alpha$-helix at the amino terminus (N) and a Bsheet at the carboxy terminus (C).

RI binds to, and inhibits the action of ribonucleases (RNases). In this way it is thought to regulate RNA turnover. LRR are found in a wide variety of proteins with functions ranging from cell adhesion to DNA repair. The common thread that links the diverse members of the LRR superfamily together is their participation in protein-protein interactions.

How does RI bind so tightly to RNases? Biochemical data suggest that the interactions occur through the wall of $\beta$ sheet lining the inside of the horse shoe and the $\beta \alpha$ loops on 'top' of the molecule. The diameter of the cavity in the centre of the protein (18-24 $\AA$ ) could only accommodate part of RNase A $(20 \times 25 \times 45 \AA)$. Formation of the complex might require flexibility in the polypeptide chain at the ends of the horse shoe.

Notably, the wall of $\beta$-sheet lining the inside of the horse shoe lacks the twist typically seen in parallel $\beta$-barrel structures. The radius of the horse shoe is therefore determined by the differences in the distance between the stands and helices. In the case of RI the two ends of the horseshoe would meet after 21 repeats. Other proteins with larger numbers of repeats could avoid such a clash by twisting the $\beta$-sheet to give a helical molecule or parcelling the repeats up into smaller domains. 